\title{
Diaspora-Building and Cultural Diplomacy: The Greek Community of Jerusalem in Late Ottoman Times and the Mandate
}

\author{
Konstantinos Papastathis
}

This chapter elaborates on the history of the Greek diasporic community of Jerusalem in late Ottoman times and the formative years of the British Mandate. In particular, it focuses on the creation of the Greek Colony, with the so-called Greek Club at its centre, as well as the role of Greek cultural diplomacy in its development. Overall, this chapter highlights the relationships between the Greek state, the Orthodox Patriarchate and the establishment and development of the Jerusalem Greek diaspora. By relying mainly on Greek sources, such as the state archives or the journal Nea Sion, published by the Jerusalem Patriarchate, this chapter particularly foregrounds the diaspora community's own worldview, understanding of their place in Jerusalem and Palestine, and cultural relations with the Greek state.

The members of the Greek Jerusalem community might be divided in two subgroups: emigrants from Greece itself, and those emigrants who came mainly from within the Ottoman Empire, including refugees from Turkey after the First World War. The basic feature of their social status within the Ottoman period was the millet system, which was effectively maintained during the British Mandate. According to the millet system, each religious community was under the supervision of its religious head (for example, the

K. Papastathis $(\square)$

Aristotle University of Thessaloniki, Thessaloniki, Greece

e-mail: kpapastathis@polsci.auth.gr

(C) The Author(s) 2021

255

K. Sanchez Summerer and S. Zananiri (eds.), European Cultural

Diplomacy and Arab Christians in Palestine, 1918-1948,

https://doi.org/10.1007/978-3-030-55540-5_13 
Orthodox/Rum millet under the Jerusalem patriarch). This system, however, did not imply a national grouping, but rather had a religious meaning indicating the Eastern Orthodox/Rum congregation per se. ${ }^{1}$ The Greek residents of Jerusalem, therefore, were not identified with the lay congregation. This is because its members were ethnic Arabs, closely related to the Palestinian national cause from the first stage of its building process (late Ottoman times) and with strong bonds with the Muslim majority as well. ${ }^{2}$ In short, the common religious identity did not work as the cohesive element of the group. If this were the case, the local Greeks would have integrated into the dominant Arab Orthodox community. Rather it was the language and the perception of an imagined history and shared cultural matrix which formed the criteria for defining the "in-group" versus the "outgroup". Within this framework, the national identity was not equated with the Greek nation state, but with the so-called "Ecumenical Hellenism" 3 more broadly.

Greece, as the "kin state" followed an inclusionary policy, aimed at reproducing the existing national affiliation of the Jerusalem Greeks in order to block their integration into the dominant national groups. To this end, it instrumentally articulated a discourse of "openness" and national homogeneity, and institutionalised preferential treatment for the Greek diaspora members, for instance, proffering the opportunity for dual citizenship to diaspora members. It also recognised qualifications from the Jerusalem high school as of equal status with its counterparts within the Greek state. ${ }^{4}$ However, Athens neither insistently claimed the right to officially administer the affairs of the Greek nationals of Palestine under protégé status by the British, which might indirectly challenge the political status quo; nor did it establish autonomous communal structures for the reproduction of national loyalties and cultural bonds, following the example of the Western countries, but kept major the functions of Jerusalem diasporic life under the traditional control of the Church. This might be explained by the small size of the community, the lack of financial resources and the secondary importance for Athens of developing a dependent relationship with the Greek community in Palestine compared to that of Constantinople or Smyrna (the basic aims of Greek irredentism

\footnotetext{
${ }^{1}$ Benjamin Braude, "Foundation Myths in the Millet System," in Christians and Jews in the Ottoman Empire: The Functioning of a Plural Society, eds. Benjamin Braude and Bernard Lewis (New York: Holmes and Meier Publishers, 1982), 69-89; Paraskevas Konortas, Othomanikes theoriseis gia to Oikoumeniko Patriarcheio, 17os-arches 20ou aiona (Ottoman Vetting Concerning the Ecumenical Patriarchate, from the 17th to the Beginning of the 20th Century) (Athens: Alexandreia, 1998).

${ }^{2}$ Noah Haiduc-Dale, Arab Christians in British Mandate Palestine: Communalism and Nationalism, 1917-1948 (Edinburgh: Edinburgh University Press, 2013).

${ }^{3}$ Lina Ventouras, "Deterritorialising" the Nation: The Greek State and "Ecumenical Hellenism",' in Greek Diaspora and Migration Since 1700: Society, Politics and Culture, ed. Dimitris Tziovas (London and New York: Routledge, 2016), 125-140.

4 "Decision of the Greek Ministry of Education and Cults," Nea Sion 11 (1911): 908.
} 
at the time, the so-called Megali Idea (Great Idea), for the accomplishment of which the British support was imperative). Such a policy would, anyway, have been barred by the fact that London would never allow foreign powers to interfere in the affairs of their Mandate, i.e. the continuation of the capitulations regime. Within this framework, foreign state powers had been granted the right to protect their subjects residing in the Ottoman Empire, as well as the affiliated clergy. ${ }^{5}$ The creation of an imperium in imperio within the boundaries of its Mandate completely unacceptable by the new Administration, as the British Prime Minister Lloyd George made clear in the London Peace Conference of February $1920 .^{6}$

Except for the diasporic community, the main Greek pillar in Jerusalem was the Orthodox Patriarchate, the administration of which has been in the hands of Greek and Cypriot clergymen, practically to the exclusion of other Orthodox national groups. Overall, the "politicisation" of the religious sphere in the late Ottoman period entailed a gradual transformation of the Patriarchate's organisational structures from non-national sectarian representation to nationally based communal affiliation. ${ }^{7}$ Greek control was the outcome of a Hellenisation process of the institution from the nineteenth century onwards on the basis of the ethno-phyletist narrative of HellenoOrthodoxia. In short, this myth advocates the primordial and essentialist equation of Orthodoxy with the Greek nation. The one presupposes the other: Greek means Orthodox and vice versa. ${ }^{8}$ The imagined self-fulfilment of the Church, therefore, lay in promoting the alleged national "good". Within this context, Athens as the nation's centre should be the political agent, with which every Orthodox subject (and thus Greek) should identify itself. The hegemony of Helleno-Orthodoxia within the Jerusalem Brotherhood meant that the definition of the "us" vs. "them" distinction was made along ethnic lines; thus, the other Orthodox nations as "out-groups" formed an "enemy", and their claims over the common religious framework were more or less demonised and treated as an attempt to corrupt religious purity. In effect, the Patriarchate of Jerusalem must as a matter of principle remain in Greek

\footnotetext{
${ }^{5}$ Catherine Nicault, "La fin du protectorat religieux de la France à Jerusalem (1918-1924)," Bulletin du Centre de recherche français à Jérusalem 4 (1999): 7-24; Roderick H. Davison, “'Russian Skill and Turkish Imbecility': The Treaty of Kuchuk Kainardji Reconsidered," Slavic Review 35, no. 3 (1976): 463-483.

${ }^{6}$ E. L. Woodward and Rohan Butler, Documents on British Foreign Policy (1919-1939), First Series (London: H. M. Stationary Office, 1958), vol. 7, 103-111.

${ }^{7}$ Konstantinos Papastathis, "Religious Politics in Mandate Palestine: The Christian Orthodox Community Controversy in the Thirties," British Journal of Middle Eastern Studies 43, no. 3 (2016): 265.

${ }^{8}$ Paraskevas Matalas, "To Patriarcheio Ierosolimon kai I ellino-orthodoxia," ("The Patriarchate of Jerusalem and helleno-orthodoxia") in Orthodoxia, Ethnos kai Ideologia (Orthodoxy, Nation and Ideology) (Athens: Moraiti School, 2007), 116.
} 
hands, while the Arabs, Russians, Georgians, etc. had to accept their inferior status within the institution. ${ }^{9}$

This Greek "invented tradition" was contested by the indigenous Arab Orthodox, who viewed it as cultural imperialism. According to the Arab Orthodox side, the dominance of the ethnic Greek element at its expense had to end. The Arab laity followed with Russian support the example of other Orthodox ethnic groups within the empire (the Bulgarian Exarchate, Orthodox Arabs in Antioch) and demanded the laicisation of communal power structures, the gradual removal of the foreign Greek hierarchy and the subsequent takeover of ecclesiastical power by the indigenous Arabs. ${ }^{10}$ This question was also linked to the management of the communal finances and property, which were under the exclusive control of the Greek clergy. For the Arab Orthodox, the Greek establishment was the hostile other that had usurped local religious patrimony and property. ${ }^{11}$ Because this type of cultural and economic imperialism was viewed as unacceptable, the Arab Orthodox community demanded co-administration of finances and control of the sale of land through the establishment of a joint community body, the so-called Mixed Council. However, this question was not only a matter of gaining access to key sources of revenue; as part of the Arab-Zionist rivalry for domination over Palestine, it also affected the political position of the indigenous Arab Christians. ${ }^{12}$

As regards the patriarchate, the strategic aim of Athens was the preservation of its Greek national character. Greece's political positioning vis-àvis this institution can be divided into two stages during the Mandate. The first, which roughly covers the period 1917-1920, was characterised by Athens' vigorous intervention into the affairs of the patriarchate. For Athens, regime change was seen as an opportunity to establish the national centre's direct rule over the patriarchate. However, the British blocked this attempt due to domestic as well as international considerations. Despite this, Greece

\footnotetext{
${ }^{9}$ Konstantinos Papastathis, "Secularizing the Sacred: The Orthodox Church of Jerusalem as a Representative of Greek Nationalism in the Holy Land," in Modern Greek Studies-Yearbook 2014/15 (Minneapolis: University of Minnesota, 2016), 37-54.

${ }^{10}$ Derek Hopwood, The Russian Presence in Syria and Palestine, 1843-1914: Church and Politics in the Near East (Oxford: Clarendon Press, 1969); Theophanes G. Stavrou, Russian Interests in Palestine, 1882-1914: A Study of Religious and Educational Enterprise (Thessaloniki: Institute for Balkan Studies, 1963); Abdul Latif Tibawi, Russian Cultural Penetration of SyriaPalestine in the Nineteenth Century (London: Luzav and Co., 1966); Elena Astafieva, "La Russie en Terre Sainte: le cas de la Société Impériale Orthodoxe de Palestine (1882-1917)," Cristianesimo nella Storia 24 (2003): 41-68.

${ }^{11}$ Itamar Katz and Ruth Kark, "The Greek Orthodox Patriarchate of Jerusalem and Its Congregation: Dissent over Real Estate," International Journal of Middle East Studies 37 (2005): 509-534; Itamar Katz and Ruth Kark, "The Church and Landed Property: The Greek Orthodox Patriarchate of Jerusalem," Middle Eastern Studies 43 (2007): 383-408.

${ }^{12}$ Konstantinos Papastathis and Ruth Kark, "Colonialism and Religious Power Politics: The Question of New Regulations within the Orthodox Church of Jerusalem During the British Mandate," Middle Eastern Studies 50, no. 4 (2014): 589-605.
} 
maintained its central importance in religious administration throughout the rest of the Mandate period, but local authorities held primacy in decision-making. Greek diplomats followed developments within the institution, and got involved in various individual cases, but did not claim the right to fully control its affairs. ${ }^{13}$

\section{The Establishment and Development of the Greek Diaspora COMMUnity}

From the mid-nineteenth century, a wave of Greek emigrants from both the Ottoman Empire and Greece settled in Palestine in search of employment. In particular, we find the first Greek merchants and other professionals, such as doctors and pharmacists, in Acre and Jaffa. ${ }^{14}$ The Greeks who settled in Jerusalem around the same period were not only professionals, but also pilgrims and the relatives of the church officials. However, the loose bonds between them, or the absence of an organised structure administered by the Greek state for their unity, did not make for the effective establishment of a diasporic community with a clear national character. On the contrary, in this early phase of the Greek communal presence in Palestine (in the mid nineteenth century), a significant proportion of its members was gradually acculturated into the Arab dominant group. ${ }^{15}$

This development was further fuelled by the fact that not all members of the community had as their spatial point of departure the Greek state, but belonged to the wider social context of the Rum Orthodox group of the Ottoman Empire, the nationalisation process of which was in its early phase. In short, the Rum Orthodox emigrant in Palestine was not by definition identified with the Greek "imagined community"; because of this volatile identity, he/she was more prone to an identity shift process which involved integrating into the dominant Arab group, especially at a time when the Greek national community was small. To sum up, the Greek nationals did not form at that period a cohesive group or at least a solidarity network like the other national communities. On the other hand, another possibility might be that some "arabised" Greeks could have been in reality indigenous Arabs, who had taken the Greek citizenship on the grounds of their religious affiliation, due to the financial and diplomatic privileges provided in the Capitulation Treaty of Kalitza between Greece and the Sublime Porte in

\footnotetext{
${ }^{13}$ Konstantinos Papastathis, "Greece in the Holy Land During the British Mandate: Diplomacy and Religion," Jerusalem Quarterly 71 (special issue "History of Diplomacy in the Holy Land', ed. R. Mazza) (2017): 30-42.

${ }^{14}$ Diplomatic and Historic Archive of the Greek Ministry of Foreign Affairs (hereafter GFOA): File 104. Subfile. 6, 1946, Directorate for Studies. Note of Konstantinos Ch. Mavrides, Note on Palestine (Communities, Education and Greek Schools, Church, Greek Press, Greek Residents in Palestine), 2.

${ }^{15}$ Ibid., 3.
} 
1855. In short, part of this group, considered by the highly regarded secretary of the Greek Consulate in Jerusalem Constantinos Mavridis to be "Arabised" Greeks, might have actually been Arabs who had taken up Greek citizenship in order to profit from the new commercial links, as it happened in Egypt. ${ }^{16}$

On the other hand, this is not the case for late nineteenth century, when the Greek nation-building process was crystallised, and especially after the establishment of the Mandate. The Greek emigrants in Palestine shared the same language, collective cultural consciousness and common sense of ethnic belonging. In effect, they did not integrate into the dominant community, despite its close contact with the local Orthodox Arabs, but kept their separate Greek identity and loyalty to the new national centre, ${ }^{17}$ but not towards the Patriarchate of Constantinople as the old non-national sectarian representative of communal authority within the empire, but towards the political structure of the Greek nation state. On the one hand, the two groups had a common religious identity and in some cases shared the same churches, where both languages were used in religious ceremonies. On the other, a large proportion of the Greek residents spoke their mother tongue as their everyday language, and attended mass, where Greek was exclusively used; many of them were settled in a delimited area of Jerusalem (the so-called Greek Colony), sent their children to different schools and frequented different social clubs. In short, the fact that the two groups had close links did not signify their fusion into a cohesive communal whole, for they actually remained separate from one another. ${ }^{18}$

According to the census of 1922 the Greek-speaking population in Palestine numbered 1230 persons, among whom 700 lived in Jerusalem. ${ }^{19}$ The community grew further during the Mandate. In 1945 Greek speakers

\footnotetext{
${ }^{16}$ Katerina Trimi-Kyrou, "Endoparoikiaka Kinitra kai to Opsimo Elladiko Endiaferon gia tous Michanismous Sygkrotisis kai Empedosis tis Ellinikis Ethnikis Tautotitas stis Paroikies tis Aigyptou" ("Intra-Diaspora Motives and the Late Greek Interest in the Formation and Consolidation Mechanisms of the Greek National Identity in the Egyptian Diaspora"), in To Ethnos peran ton Synoron (The Nation Beyond the Borders), eds. Lina Ventoura and Lampros Mpaltsiotis (Athens: Vivliorama, 2013), 258.

${ }^{17}$ Merav Mack, Angelos Dalachanis and Vincent Lemire, "Matrimony and Baptism: Changing Landscapes in Greek (Rum) Orthodox Jerusalem (1900-1940)," British Journal of Middle Eastern Studies 45, no. 3 (2018): 448-451.

${ }^{18}$ Merav Mack, "United by Faith, Divided by Language: The Orthodox in Jerusalem," in Arabic and Its Alternatives: Religious Minorities and Their Languages in the Emerging Nation States of the Middle East (1920-1950), eds. Heleen Murre-van den Berg, Karène Sanchez Summerer and Tijmen Baarda (Leiden: Brill, 2020); Konstantinos Papastathis, "Arabic vs Greek: The Linguistic Aspect of the Jerusalem Orthodox Church Controversy in Late Ottoman Times and the British Mandate," in Arabic and Its Alternatives: Religious Minorities and Their Languages in the Emerging Nation States of the Middle East (1920-1950), eds. Heleen Murre-van den Berg, Karène Sanchez Summerer and Tijmen Baarda (Leiden: Brill, 2020).

${ }^{19}$ J. B. Barron, Palestine: Report and General Abstract of the Census of Palestine, 1922 (Jerusalem: Greek Convent Press, 1922), 57.
} 
in Palestine numbered around 2000, 1500 of whom resided in Jerusalem. This number does not include Jewish emigrants from Greece, estimated at around 3000 persons..$^{20}$ In the end of the Mandate, the value of their immovable property was estimated at around two million English pounds, while their movable property reached the sum of twelve hundred thousand English pounds. The Greek funds invested amounted to five hundred thousand English pounds, while more than a hundred companies and firms (café, restaurants, drag stores, cinema, etc.) were in Greek hands. Last but not least, the Greek shipping business was very active in the Haifa port, the hub of economic and industrial activity under the Mandate. ${ }^{21}$

The Greek community in Jerusalem was institutionally established around an organised diasporic structure from 1902, in the form of an Association named "I Eypoiia" by the initiative of the general Consul of Greece I. Alexandropoulos. It seems, however, that the Association was more grounded in the activities of a pioneering middle- and upper-class group of Jerusalem Greeks who wanted to create a national solidarity network within a foreign social environment, rather than being the outcome of a well-structured cultural diplomatic strategy of Athens. The initial was the unity of the Greek nationals, and then the creation of the infrastructures necessary to acquire the status of a national community; the transformation of its character from "Greek-Orthodox", to properly "Greek", independent from the Patriarchate's control. However, paradoxically, it was actually the Patriarchate that indirectly supported this project, via the financial backing of the sacris$\tan$ of the Holy Sepulchre archimandrite Euthymios. ${ }^{22}$ This is because the Patriarchate did not have, according to the Ottoman legal system, the necessary recognition as a legal entity and was thus not eligible to purchase rural (miri) and private (mulk) land. To tackle this problem, the Patriarchate could practically register miri property only as a wakf (religious endowment), and had to register the title deeds of mulk property under the name of a religious official as a proxy, who afterwards endowed their use and the revenues coming from it (e.g. rents) to his religious institution, as a wakf.

${ }^{20}$ GFOA: File 104. Subfile. 6, 1946, Directorate for Studies. Note of Konstantinos Ch. Mavrides, Note on Palestine (Communities, Education and Greek Schools, Church, Greek Press, Greek Residents in Palestine), 37.

${ }^{21}$ GFOA: KY 1948, File 25, Subfile 4, Greek Diaspora, I.A.K. Tziras (Director of Financial Affairs/Greek Minsitry of Foreigh Affairs) to the Church and Diaspora Directorate (10 March 1948), reg. num. 2013.

${ }^{22}$ Although Euthymios never became a patriarch (he actually lost the See by Damianos in 1895) he was probably the most important religious official in Jerusalem Church, due to his financial capabilities and his charitable work. Particularly, he administered the purchase of large tracks of land where buildings and markets were constructed. In fact, the current real estate portfolio of the Patriarchate was to a large extent built by Euthymios. Moreover, being an openminded clergyman, he established the School of Holy Cross and influenced important figures of the Jerusalem Church, such as Meletios Metaxakis and Chrysostomos Papadopoulos. In short, he left his imprint in the contemporary history of the Jerusalem Church. 
To facilitate the use of this legal device, many religious institutions, such as the Jerusalem Patriarchate, were structured according to the idiorrhythmic pattern of monastic function. This means that each monk had the right of private ownership, which was compulsorily donated or bequeathed to his institution. ${ }^{23}$ Within this legal context, it seems problematic that Euthymios' donation to the Greek community did not have the approval of his institution. Besides, it was common practice for the Patriarchate to support the Greek emigrants, providing properties to reside within the Walls of Jerusalem or leasing real estate for building outside the Old City. For instance, Nicholas Spyridon, president of the Greek Club in 1920s, lived in the 1890s in the Old City in a property of the Patriarchate and later moved to another in Mamilla, which was also lent by the Greek Convent. ${ }^{24}$

Euthymius contributed in the first place a loan of three thousand gold francs, which was added to the initial capital of ten thousand francs collected by the Greek Association. With the sum of thirteen thousand golden francs, the Association bought from the Greek Orthodox Monastery of Katamon a hundred thousand square pics (according to the Ottoman unit of area metric system 1 sq. pic $=$ approximately 0.574 sq. metre) in the area between the German Colony and the Monastery. This property was divided into eighty parcels, and distributed to the Association's members on the condition that they should build a house on their share. ${ }^{25}$ The distribution of the plots was made by drawing lots and the construction of the buildings was made on extremely advantageous terms. In particular, the houses were in the first place funded by the Association, and the equivalent sum was afterwards repaid by the owner in small instalments with a low interest rate. In this way, it was possible to create a stable and dynamic community in Jerusalem, the members of which resided in the same district, the so-called Greek Colony. The first twenty homes were designed by architect Spyros Houri. ${ }^{26}$ At a later stage, Euthymios donated another property of a hundred thousand square pics closer to the Katamon Monastery. The Greek Colony was divided into two neighbourhoods, not far from one another: the old "lower" district' and the new "upper" district in Baq'a. The new parcels of land and the houses constructed there were allocated to the Greeks of Jerusalem on the same terms and conditions as the previous ballot. Moreover, Euthymios funded

\footnotetext{
${ }^{23}$ Konstantinos Papastathis and Ruth Kark, "The Politics of Church Land Administration: The Case of the Orthodox Patriarchate of Jerusalem in Ottoman and Mandatory Palestine," Byzantine and Modern Greek Studies 40, no. 2 (2016): 264-282.

${ }^{24}$ Rochelle Davis, "Ottoman Jerusalem: The Growth of the City Outside the City Walls," in Jerusalem 1948: The Arab Neighbourhoods and Their Fate in the War, ed. Salim Tamari (Jerusalem: The Institute of Jerusalem Studies \& Badil Resource Centre, 2002), 19.

${ }^{25}$ GFOA: File 39. Subfile 3. 1923. Part 1, Greek Association of Jerusalem to the Greek General Consul, 26 January 1923, reg. num. 9.

${ }^{26}$ Ruth Kark and Michal Oren-Nordheim, Jerusalem and Its Environs: Quarter, Neighbourhoods, Villages, 1800-1948 (Detroit: Wayne State University Press, 2001), 173.
} 
the construction of a building, the so-called Greek Club (Leschi in Greek) of Jerusalem, serving as a centre of the community with a central hall, a library, a small museum and two more rooms that served at a later stage as a kindergarten and an apartment for the teacher. ${ }^{27}$ Concerts, plays and film screenings were often organised in the Greek Club. It also served as an everyday meeting place for families and children. ${ }^{28}$ The affairs of the Greek Colony were administered by a five-member permanent committee, appointed by Euthymios, together with the Greek consul.

\section{The Jerusalem Greek Diaspora in the Mandate}

The flourishing of the Jerusalem diaspora halted with World War One, when the Ottomans considered Greeks to be "fifth column" and kept the community leadership in custody. Despite the efforts of the Patriarchate to protect them, intervening with the authorities on their behalf, a number of Greeks were exiled to Aleppo in Syria and Maras in Cilicia. Their return to Jerusalem found them in a very financial bad state, as a result of which they were forced to sell their properties. Almost three-quarters of the estates of the Greek Colony were sold at this time, reducing the Greek properties to around a quarter of the original plus those properties belonging to the community as an institution, such as the Greek Club.

The British Mandate marked a shift in the administration of communal affairs. From the quasi-oligarchical rule of the permanent five-member committee, a new community charter was put into force in mid-March 1922, drawn up by a twelve-member committee under the supervision of the Greek General Consul Demetrios Mpenetatos. ${ }^{29}$ The Greek national character of the Colony, as well as the institutional lacuna with regard to its administration, was further covered by the Special Regulation of the Greek Colony enacted by the General Assembly of the Club together with the new Charter. According to it, the basic aims of the Club were the unity of the Jerusalem Greek population; the maintenance and expansion of the Greek Colony; and the establishment and maintenance of charitable institutions and schools to serve the needs of the community. The five-member permanent committee would continue to exist in a quasi-titular capacity, maintaining responsible only for administering the equity capital donated by Euthymios for the Greek Colony. On the other hand, the administration of the general affairs and finances of the Greek Club and the Colony would be managed by an elected

${ }^{27}$ GFOA: File 39. Subfile 3. 1923. Part 1, Greek Association of Jerusalem to the Greek General Consul, 26 January 1923, reg. num. 9.

${ }^{28}$ Rochelle Davis, "The Growth of the Western Communities, 1917-1948," in Jerusalem 1948: The Arab Neighbourhoods and Their Fate in the War, ed. Salim Tamari (Jerusalem: The Institute of Jerusalem Studies \& Badil Resource Centre, 2002), 57.

${ }^{29}$ GFOA: File 104. Subfile. 6, 1946, Directorate for Studies. Note of Konstantinos Ch. Mavrides, Note on Palestine (Communities, Education and Greek Schools, Church, Greek Press, Greek Residents in Palestine), 4-6. 
seven-member Committee. The competent body for electing its members was the General Assembly of the Community. ${ }^{30}$

The central features of the Charter were two. One the one hand, it had an "exclusionist" character, in the sense that it aimed to foster national homogeneity within the community, restricting the enrolment of members to a single ethnic criterion, despite the fact that many properties within the Colony were already sold to non-Greek nationals. On the other hand, the Charter institutionally established the indirect control of the Community by the Greek Consulate. The Community was no longer an independent public body, but was officially under the influence of a foreign country. The request to the Athens Government to recognise the Club as a legal entity under public law should be viewed within this framework. ${ }^{31}$ In short, the Club effectively became a branch of the Greek Administration. Certain clauses of the Charter point to this conclusion. In particular, all the adult Greeks of Jerusalem could become a due-paying member of the Club, while non-Greeks could enrol only on condition their registration was approved by the Club's Council. The Greek Consul of Jerusalem was ex officio the president-emeritus of the Club, and responsible for supervising and controlling its Council and administration. As far as the Greek Colony was concerned, the Club's Charter stipulated that three-quarters of the annual fees should be allocated for the construction of new buildings. Moreover, to avoid the sale of properties to non-Greeks, as had happened during and immediately after the Great War, the Charter prohibited the owner of a property from selling it, and defined the Club's Council as the competent authority for any transaction of real estate within the Colony. ${ }^{32}$

Contrary to the expectations of Jerusalem Greeks, Patriarch Damianos was against the establishment of an organised diasporic community. He did not support either the creation of a communal structure, nor its naming as "Greek", because he considered the Patriarchate and himself as its head to be the sole representative of Hellenism in the Holy Land. In brief, he regarded the institutionalisation of the diaspora community as a legal body representing the Greek national identity to be against the patriarchate's interest. ${ }^{33}$ Another reason might be that Damianos did not enjoy the support of the community in his dispute with the other members of the Brotherhood, who were backed by the Greek consul Benetatos. The Club's Council considered Damianos' policy to be damaging to national interests, "reprobate and

\footnotetext{
${ }^{30}$ Charter of the Greek Association of Jerusalem, 1902-1922 (Jerusalem: Holy Convent Printing Press).

${ }^{31}$ GFOA: File 39. Subfile 3. 1923. Part 1, Greek Association of Jerusalem to the Greek General Consul, 26 January 1923, reg. num. 9.

32 Charter of the Greek Association of Jerusalem.

${ }^{33}$ GFOA: File 104. Subfile. 6, 1946, Directorate for Studies. Note of Konstantinos Ch. Mavrides, Note on Palestine (Communities, Education and Greek Schools, Church, Greek Press, Greek Residents in Palestine), 5-6.
} 
unpardonable", as well as for his indifference to education and the endemic corruption within the institution. ${ }^{34}$ Why, therefore, would Damianos be in favour of the establishment of a body that would not only control, but actually operate against, his power? Another reason for Damianos' refusal might be the potential threat that the Greek "community" might claim co-administration of church finances, following the example of the Arab Orthodox. This case would further complicate the position of the Patriarchate. For these reasons, the new institution was actually named "the Greek Club" instead of "Greek Community", as the intention of the organisers had initially been. It was only after Damianos' death in 1931 that the "Greek Club" was finally entitled "Greek Community of Jerusalem".

In effect, two camps were created among the Jerusalem Greeks in the early twenties. On the one hand was Patriarch Damianos and the majority of the Greek hierarchy. On the other, the Greek diplomatic representatives together with the Greek diasporic community and some clergymen of the Brotherhood. It should be noted that the existence of the ethnic Greeks in Jerusalem was not directly related to the controversy between the Arab congregation and the Greek religious establishment, because the diaspora group did not work as a pool from which to recruit members for the Brotherhood, nor did the hierarchy plead its authority or base its claim of the patriarchate's Greek character on the basis of the city's Greek diaspora. In short, any equation between the Brotherhood and the ethnic Greek community in Jerusalem is not historically substantiated. Of course, this does not exclude interaction between the two actors, which was always very close. However, the Greek Brotherhood/Arab congregation divide was an affair strictly of the hierarchy. It was not the Greek diaspora's war.

To address the hegemonic tendencies of Damianos, who perceived his power as absolute within the Greek community, the Greek Club adopted a policy of diversifying the institution away from the Patriarchate. The community asked for direct funding from Athens, without the mediation of the patriarchate, and demanded the creation of a school network under communal supervision, excluding church control. ${ }^{35}$ The Patriarchate was the main pillar of Greek education in Palestine, but in the 1920s it was in a state of severe financial crisis, with debts that had reached the sum of five hundred thousand Egyptian pounds. ${ }^{36}$ Its power, therefore, to properly finance the communal schools was limited. The reduction in 1923 of the Jerusalem Greek High School teachers' salaries by up to one-third of their initial income

\footnotetext{
${ }^{34}$ GFOA: File 39, Subfile 3, 1923, part 1, Jerusalem Greek Association to the Greek Ministry of Foreign Affairs, 1 July 1923, reg. num. 20.

${ }^{35}$ Ibid.

${ }^{36}$ Anton Bertram and Charles H. Luke, Report of the Commission Appointed by the Government of Palestine to Inquire into the Affairs of the Orthodox Patriarchate of Jerusalem (London: Oxford University Press, 1921).
} 
is indicative. ${ }^{37}$ Because of the patriarchate's poor state, Greece contributed from time to time to its operation, and the Club fundraised as well. ${ }^{38}$ The working language of the Orthodox schooling network was Arabic, while basic Greek was taught in some classes. Greek was the teaching language of at least some courses in the Greek High School of Jerusalem, and of two girls' schools in Jerusalem and Bethlehem. Since the school network at that time was in the hands of the Patriarchate, the Greek community was not institutionally involved in the administration. A major reason for this was the Arab Orthodox demand to participate in managing communal education. In short, if the small Greek diasporic group had a say in educational affairs, the large Arab congregation would have demanded at least the same status. In effect, the Greek religious establishment would have to give away its absolute power in this important sphere with major impacts on its overall conflict with the Arab Orthodox. Neither Athens nor the Greeks in Jerusalem were in favour of such a development.

The rejection of the community's proposal to open a Greek school under its direct supervision was both financial and political. Athens could not fund the community of Jerusalem on a permanent basis. The huge refugee wave from Asia Minor due to the exchange of population between Greece and Turkey, as well as the financial condition of the Greek State, made this difficult. Moreover, it would have created tensions with the British Administration, which might view Athens' intervention as part of a hidden agenda to establish protégé rights within Palestine. Furthermore, it would have widened the rift between the Patriarchate and the Greek Club, as well as between the Greek and the Arab Orthodox. ${ }^{39}$ It should be noted that until the late thirties, the funding of the Orthodox school network depended upon the decisions of the Financial Commission, managing all the financial affairs of the Patriarchate. In effect, the education of Greek youth was an open question within the power game between the Patriarchate, the Arab congregation and the British Administration.

In particular, a sub-commission was established to manage the funds for the Orthodox schools, comprised of two patriarchal representatives, two representatives from the Arab congregation, a member of the Financial Commission and a representative from the Directorate of Education of the British Administration. The Arab representative, Elias Moushabek, openly demanded that the Greek Orthodox High School of Jerusalem should focus on Arab students $\mathrm{He}$ argued that it was not rational to expend so many resources on a few Greek students, when there were so many Arabs without a proper education. For him, the Greek State should be responsible for the

\footnotetext{
${ }^{37}$ GFOA: File 39, Subfile 3, 1923 part 2, Mpenetatos to the Greek Ministry of Foreign Affairs, 20 October 1923, reg. num. 32600.

${ }^{38}$ Ibid.

${ }^{39}$ GFOA: File 39, Subfile 3, 1923 part 1, Greek Ministry of Foreign Affairs to Mpenetatos, 29 August 1923, reg. num. 23979.
} 
education of ethnically or nationally Greek students, not the Patriarchate, as it was the case for French or Italian students, whose institutions were established by their countries of origin. The British were not against this formula, but it was blocked by the Greek hierarchy on the grounds that the sub-commission was exceeding its responsibilities, which were not to administer the school network, but to find resources to fund its operation. ${ }^{40}$ In other words, if Athens were to fund the establishment of Greek schools under its direct supervision or the supervision of the Greek community, independent of the existing structures under the control of the Patriarchate as requested by Moushabek, the existing school network under patriarchal supervision would have been gradually "arabised"; a development considered to be a step towards the overall loss of the supposed Greek character of the Jerusalem Orthodox Church, the aversion of which was actually Athens' central strategic aim in Mandate Palestine.

The only ethnic-centred education establishment created was the kindergarten set up within the Greek colony in $1907 .{ }^{41}$ It was closed during the war and reopened for just one year afterwards, but closed again due to the lack of funds, estimated at between fifty and eighty pounds per year. Neither the community nor the Patriarchate could provide this amount, and Athens at that time had other priorities. ${ }^{42}$ However, in 1923, Athens sent 400 Egyptian Pounds to the community with which a communal grocery store was established, the revenues from which were used to run the communal kindergarten. ${ }^{43}$ Moreover, Athens financially supported the primary school of the Greek Community in Haifa (an annual sum of 25 Egyptian Pounds), as well as the Greek section within the Arab Orthodox school of Jaffa, established in 1930 by the local Greek community "Omonoia" (the annual sum of 25 Egyptian Pounds).

Besides the Greek Club, the Jerusalem diasporic community administered other institutions operating under its umbrella. These were a music association; the Greek Charity Association of Jerusalem; The Odigitria Greek Ladies Club (the Charity Association and the Ladies Club were unified in 1938); the Greek Scouting Association; and the Heracles Sports Club (unified with the Scouting Association in 1934). In 1945 the Olympiakos Football Club was established, despite the objection of the communal leadership, which

${ }^{40}$ GFOA: File 39, Subfile 3, 1923 part 1, Mpenetatos to the Greek Ministry of Foreign Affairs, 14 July 1922, reg. num. 378.

${ }^{41}$ GFOA: File 104. Subfile. 6, 1946, Directorate for Studies. Note of Konstantinos Ch. Mavrides, Note on Palestine (Communities, Education and Greek Schools, Church, Greek Press, Greek Residents in Palestine), 6.

${ }^{42}$ GFOA: File 39, Subfile 3, 1923 part 1, Mpenetatos to the Greek Ministry of Foreign Affairs, 28 May 1922, reg. num. 334.

${ }^{43}$ GFOA: File 104. Subfile. 6, 1946, Directorate for Studies. Note of Konstantinos Ch. Mavrides, Note on Palestine (Communities, Education and Greek Schools, Church, Greek Press, Greek Residents in Palestine), 6. 
was not involved in its management. The first newspaper of the Greek diaspora in Jerusalem, entitled Palestine, was established in 1908 and published weekly. However, because of the Arab Orthodox uprising against the Greek Church elite in 1908, the newspaper's print shop was destroyed, allegedly by Arab Orthodox extremists. It was later re-established in Cairo by its original publisher Michalis Eustathiades, but this was a short-lived enterprise. The Gazette of the Patriarchate, Nea Sion, was created four years earlier in 1904. It had a religious character, but also contained much information about the affairs of the local Greek community. In 1940 the weekly newspaper KYRIX was established but closed within a short time. Finally, the newspaper Elliniki $Z O I$ was founded in September 1945 under the management and editorial supervision of the Greek community of Jerusalem.

\section{CONCLUSION}

During the period under examination, interactions between the Jerusalem Greek diaspora and the local Patriarchate were very close. The Patriarchate as an institution had political power, exercised judicial authority, controlled the school network and funded the activities of the Greek diaspora, such as the establishment of the Greek Colony. However, the existence of the ethnic Greek group in Jerusalem did not intervene in church administration as it did elsewhere in the Ottoman Empire. For this reason, it was not directly related to the controversy between the Arab congregation and the Greek religious establishment. As far as the policy of Athens was concerned, it tried after the First World War to exercise protective powers in Palestine over both the Patriarchate and the Greek ethnic community but without any success, due to the intervention of the British authorities. The Greek consulate was an important actor in communal affairs, but was not the central one. From an institutional perspective, the British did not allow Greece to acquire rights of protection over the Greek nationals. Athens could not therefore create the forms of political dependency within the framework of a give and take, clientelist relationship, which would have allowed Greek diplomacy to become a necessary mediator for dealing with the administrative and financial affairs of Greek nationals. Moreover, Athens did not support the community and its various institutions financially and on a regular basis. As such, it could not control decision-making within the community. It seems, therefore, that its influence depended more on ideology, i.e. the national loyalties of the diaspora, rather than on its actual capacity to play the role of effective agent for the material and political well-being of the Greeks in Palestine.

This article, of course, by no means comprehensively treats the theme of the Jerusalem Greek diasporic history in the period under discussion. Much new research must be done to understand more fully the diverse aspects of this broad thematic, such as relations between the Greek diaspora of Palestine and Egypt, or the disinclination of Greece to adopt an "inclusionary" diplomatic policy towards social groups which might have been 
open to integration into the national body, or at least to interaction with it, such as the indigenous Orthodox population or the incoming Jews from Greece. The disclosure and digitisation of documents, and especially access to the Orthodox Church archives, would be significant steps in facilitating this research. This article aspires to contribute some initial steps towards this development.

\section{BIBLIOGRAPHY}

Astafieva, Elena. "La Russie en Terre Sainte: le cas de la Société Impériale Orthodoxe de Palestine (1882-1917)." Cristianesimo nella Storia 24 (2003): 41-68.

Barron, J. B. Palestine: Report and General Abstract of the Census of Palestine, 1922. Jerusalem: Greek Convent Press, 1922.

Bertram, Anton and Charles H. Luke. Report of the Commission Appointed by the Government of Palestine to Inquire into the Affairs of the Orthodox Patriarchate of Jerusalem. London: Oxford University Press, 1921.

Braude, Benjamin. "Foundation Myths in the Millet System." In Christians and Jews in the Ottoman Empire: The Functioning of a Plural Society, edited by Benjamin Braude and Bernard Lewis, 69-89. New York: Holmes and Meier Publishers, 1982.

Charter of the Greek Association of Jerusalem, 1902-1922. Jerusalem: Holy Convent Printing Press.

Davis, Rochelle. "Ottoman Jerusalem: The Growth of the City Outside the City Walls." In Jerusalem 1948: The Arab Neighbourboods and Their Fate in the War, edited by Salim Tamari, 10-29. Jerusalem: The Institute of Jerusalem Studies \& Badil Resource Centre, 2002.

- "The Growth of the Western Communities, 1917-1948." In Jerusalem 1948: The Arab Neighbourboods and Their Fate in the War, edited by Salim Tamari, 30-67. Jerusalem: The Institute of Jerusalem Studies \& Badil Resource Centre, 2002.

Davison, Roderick H. “'Russian Skill and Turkish Imbecility': The Treaty of Kuchuk Kainardji Reconsidered.” Slavic Review 35, no. 3 (1976): 463-483.

"Decision of the Greek Ministry of Education and Cults," Nea Sion 11 (1911): 908.

Haiduc-Dale, Noah. Arab Christians in British Mandate Palestine: Communalism and Nationalism, 1917-1948. Edinburgh: Edinburg University Press, 2013.

Hopwood, Derek. The Russian Presence in Syria and Palestine, 1843-1914: Church and Politics in the Near East. Oxford: Clarendon Press, 1969.

Kark, Ruth and Michal Oren-Nordheim. Jerusalem and Its Environs: Quarter, Neighbourhoods, Villages, 1800-1948. Detroit: Wayne State University Press, 2001.

Katz, Itamar and Ruth Kark. "The Greek Orthodox Patriarchate of Jerusalem and Its Congregation: Dissent over Real Estate." International Journal of Middle East Studies 37 (2005): 509-534.

- "The Church and Landed Property: The Greek Orthodox Patriarchate of Jerusalem." Middle Eastern Studies 43 (2007): 383-408.

Konortas, Paraskevas. Othomanikes theoriseis gia to Oikoumeniko Patriarcheio, 17osarches $200 u$ aiona (Ottoman Vetting Concerning the Ecumenical Patriarchate, from the 17th to the Beginning of the 20th Century). Athens: Alexandreia, 1998. 
Mack, Merav, Angelos Dalachanis, and Vincent Lemire. "Matrimony and Baptism: Changing Landscapes in Greek (Rum) Orthodox Jerusalem (1900-1940)." British Journal of Middle Eastern Studies 45, no. 3 (2018): 443-463.

. "United by Faith, Divided by Language: The Orthodox in Jerusalem." In Arabic and Its Alternatives: Religious Minorities and Their Languages in the Emerging Nation States of the Middle East (1920-1950), edited by Heleen Murrevan den Berg, Karène Sanchez Summerer, and Tijmen Baarda. Leiden: Brill, 2020.

Matalas, Paraskevas. "To Patriarcheio Ierosolimon kai I ellino-orthodoxia" ("The Patriarchate of Jerusalem and helleno-orthodoxia"). In Orthodoxia, Ethnos kai Ideologia (Orthodoxy, Nation and Ideology), 113-121. Athens: Moraiti School, 2007.

Nicault, Catherine. "La fin du protectorat religieux de la France à Jerusalem (19181924)." Bulletin du Centre de recherche français à Jérusalem 4 (1999): 7-24.

Papastathis, Konstantinos. "Religious Politics in Mandate Palestine: The Christian Orthodox Community Controversy in the Thirties." British Journal of Middle Eastern Studies 43, no. 3 (2016): 259-284.

-. "Secularizing the Sacred: The Orthodox Church of Jerusalem as a Representative of Greek Nationalism in the Holy Land." In Modern Greek StudiesYearbook 2014/15, 37-54. Minneapolis: University of Minnesota, 2016.

—. "Greece in the Holy Land During the British Mandate: Diplomacy and Religion." Jerusalem Quarterly 71 (special issue "History of Diplomacy in the Holy Land', edited by R. Mazza) (2017): 30-42.

—. "Arabic vs Greek: The Linguistic Aspect of the Jerusalem Orthodox Church Controversy in Late Ottoman Times and the British Mandate." In Arabic and Its Alternatives: Religious Minorities and Their Languages in the Emerging Nation States of the Middle East (1920-1950), edited by Heleen Murre-van den Berg, Karène Sanchez Summerer, and Tijmen Baarda. Leiden: Brill, 2020.

Papastathis, Konstantinos and Ruth Kark. "Colonialism and Religious Power Politics: The Question of New Regulations within the Orthodox Church of Jerusalem During the British Mandate." Middle Eastern Studies 50, no. 4 (2014): 589-605.

- "The Politics of Church Land Administration: The Case of the Orthodox Patriarchate of Jerusalem in Ottoman and Mandatory Palestine." Byzantine and Modern Greek Studies 40, no. 2 (2016): 264-282.

Stavrou, Theophanes G. Russian Interests in Palestine, 1882-1914: A Study of Religious and Educational Enterprise. Thessaloniki: Institute for Balkan Studies, 1963.

Tibawi, Abdul Latif. Russian Cultural Penetration of Syria-Palestine in the Nineteenth Century. London: Luzav and Co., 1966.

Trimi-Kyrou, Katerina. "Endoparoikiaka Kinitra kai to Opsimo Elladiko Endiaferon gia tous Michanismous Sygkrotisis kai Empedosis tis Ellinikis Ethnikis Tautotitas stis Paroikies tis Aigyptou" ("Intra-Diaspora Motives and the Late Greek Interest in the Formation and Consolidation Mechanisms of the Greek National Identity in the Egyptian Diaspora"). In To Ethnos peran ton Synoron (The Nation Beyond the Borders), edited by Lina Ventoura and Lampros Mpaltsiotis, 253-284. Athens: Vivliorama, 2013.

Ventouras, Lina. "Deterritorialising" the Nation: The Greek State and "Ecumenical Hellenism".' In Greek Diaspora and Migration Since 1700: Society, Politics and Culture, edited by Dimitris Tziovas, 125-140. London and New York: Routledge, 2016. 
Woodward, E. L. and Rohan Butler. Documents on British Foreign Policy (1919-1939), First Series. London: H. M. Stationary Office, 1958. Vol. 7, 103-111.

\section{Archival Material}

Diplomatic and Historic Archive of the Greek Ministry of Foreign Affairs: File 104. Subfile. 6, 1946, Directorate for Studies. Note of Konstantinos Ch. Mavrides, Note on Palestine (Communities, Education and Greek Schools, Church, Greek Press, Greek Residents in Palestine).

Diplomatic and Historic Archive of the Greek Ministry of Foreign Affairs: KY 1948, File 25, Subfile 4, Greek Diaspora, I.A.K. Tziras (Director of Financial Affairs/ Greek Minsitry of Foreigh Affairs) to the Church and Diaspora Directorate (10 March 1948), reg. num. 2013.

Diplomatic and Historic Archive of the Greek Ministry of Foreign Affairs: File 39. Subfile 3. 1923. Part 1, Greek Association of Jerusalem to the Greek General Consul, 26 January 1923, reg. num. 9.

Diplomatic and Historic Archive of the Greek Ministry of Foreign Affairs: File 39, Subfile 3, 1923, part 1, Jerusalem Greek Association to the Greek Ministry of Foreign Affairs, 1 July 1923, reg. num. 20.

Diplomatic and Historic Archive of the Greek Ministry of Foreign Affairs: File 39, Subfile 3, 1923 part 2, Mpenetatos to the Greek Ministry of Foreign Affairs, 20 October 1923, reg. num. 32600.

Diplomatic and Historic Archive of the Greek Ministry of Foreign Affairs: File 39, Subfile 3, 1923 part 1, Greek Ministry of Foreign Affairs to Mpenetatos, 29 August 1923, reg. num. 23979.

Diplomatic and Historic Archive of the Greek Ministry of Foreign Affairs: File 39, Subfile 3, 1923 part 1, Mpenetatos to the Greek Ministry of Foreign Affairs, 14 July 1922, reg. num. 378.

Diplomatic and Historic Archive of the Greek Ministry of Foreign Affairs: File 39, Subfile 3, 1923 part 1, Mpenetatos to the Greek Ministry of Foreign Affairs, 28 May 1922, reg. num. 334. 
Open Access This chapter is licensed under the terms of the Creative Commons Attribution 4.0 International License (http://creativecommons.org/licenses/ by $/ 4.0 /)$, which permits use, sharing, adaptation, distribution and reproduction in any medium or format, as long as you give appropriate credit to the original author(s) and the source, provide a link to the Creative Commons license and indicate if changes were made.

The images or other third party material in this chapter are included in the chapter's Creative Commons license, unless indicated otherwise in a credit line to the material. If material is not included in the chapter's Creative Commons license and your intended use is not permitted by statutory regulation or exceeds the permitted use, you will need to obtain permission directly from the copyright holder. 